\title{
PSIKOLOGI DAN KEPRIBADIAN MANUSIA: Perspektif Al-Qur'an Dan Pendidikan Islam
}

\author{
Aat Hidayat \\ STAIN Kudus, Jawa Tengah, Indonesia \\ aathiedayat@gmail.com
}

\begin{abstract}
Psychology and buman personality: qur'anic and islamic education perspective. One of the goals of Islamic education is to maintain and shape the human personality so that he becomes a plenary man who can maximize his role and duties as a servant devoted to Allah swt. and became the khatifah of Allah swt. on earth. For this purpose, it is necessary to formulate the human personality that will guide and guide Islamic education in carrying out its educative role. By tracing the verses of the Qur'an that speak about humans and examine them philosophically, this paper intends to reveal a comprehensive picture of the human personality according to the Qur'an and Islamic education. Through the study it was concluded that man has two sides, namely: (1) relating to personality and spiritual aspect; (2) relating to the physical as well as the physical and physical aspects. This comprehensive human personality requires the movement and the area of Islamic education to touch all aspects of man. It not only touches the cognitive aspects, but also the affective, and psychomotor aspects. The development of buman personality through comprehensive Islamic education will guide
\end{abstract}


buman beings in order to strengthen their good potential so that they can maximize their main task to worship Allah Almighty ('abid) and become khatifah of Allah swt. on earth (khaTifah fi al-ard).

Keyword: Psychology, Human Personality, Al-Qur'an, Islamic Education.

\begin{abstract}
Abstrak
Salah satu tujuan pendidikan Islam adalah menjaga dan membentuk kepribadian manusia agar ia menjadi manusia paripurna yang mampu memaksimalkan peran dan tugasnya sebagai hamba yang mengabdi kepada Allah swt. dan menjadi khalifah Allah swt. di muka bumi. Untuk tujuan ini, perlu dirumuskan kepribadian manusia yang akan menjadi panduan dan acuan pendidikan Islam dalam menjalankan peran edukatifnya. Dengan menelusuri ayat-ayat Al-Qur'an yang berbicara tentang manusia dan menelaahnya secara filosofis, tulisan ini bermaksud mengungkap gambaran komprehensif tentang kepribadian manusia menurut Al-Qur'an dan pendidikan Islam. Lewat kajian tersebut disimpulkan bahwa manusia memiliki dua sisi, yaitu: (1) berkaitan dengan kepribadian dan aspek rohaniah; (2) berkaitan dengan fisik serta aspek labiriah dan jasmaniah. Kepribadian manusia yang komprehensif ini meniscayakan gerak dan wilayah pendidikan Islam harus menyentub segala aspek manusia. Tidak hanya menyentub aspek kognitif, tapi juga aspek afektif, dan aspek psikomotorik. Pembinaan kepribadian manusia lewat pendidikan Islam yang komprehensif ini akan menuntun manusia agar bisa memperkokoh potensi baiknya sehingga ia bisa memaksimalk.an tugas utamanya untuk beribadah kepada Allah swt. ('äbid) dan menjadi khalifah Allah swt. di muka bumi (khaTifah $\overline{f i}$ al-ard).
\end{abstract}

Kata Kunci: Psikologi, Kepribadian Manusia, Al-Qur'an, Pendidikan Islam.

\title{
A. Pendahuluan
}

Al-Qur'an adalah kitabullah yang diturunkan kepada Nabi Muhammad saw. untuk segenap manusia. Di dalamnya Allah swt. menyapa akal dan perasaan manusia, mengajarkan tauhid 
kepada manusia, menyucikan manusia dengan berbagai ibadah, menunjukkan manusia kepada hal-hal yang dapat membawa kebaikan serta kemaslahatan dalam kehidupan individual dan sosial manusia, membimbing manusia kepada agama yang luhur agar mewujudkan diri, mengembangkan kepribadian manusia, serta meningkatkan diri manusia ke taraf kesempurnaan insani. Dengannya, manusia dapat mewujudkan kebahagiaan di dunia dan akhirat. ${ }^{1}$

Al-Qur'an juga mendorong manusia untuk merenungkan perihal dirinya, keajaiban penciptaannya, serta keakuratan pembentukannya. Sebab, pengenalan manusia terhadap dirinya dapat mengantarkannya pada ma'rifatullah, sebagaimana tersirat dalam Q.S. at-Ṭariq [86]: 5-7.

Maka, bendaklab manusia merenungkan, dari apa ia diciptakan. Ia diciptakan dari air yang terpancar, yang keluar dari antara tulang sulbi dan tulang dada. (Q.S. at-Ṭariq [86]: 5-7)

Berkaitan dengan hal ini, terdapat sebuah asar yang menyebutkan bahwa "Barang siapa mengenal dirinya, niscaya ia mengenal Tuban-nya."

Di samping itu, Al-Qur'an juga memuat petunjuk mengenai manusia, sifat-sifat dan keadaan psikologisnya yang berkaitan dengan pembentukan gambaran yang benar tentang kepribadian manusia, motivasi utama yang menggerakkan perilaku manusia, serta faktor-faktor yang mendasari keselarasan dan kesempurnaan kepribadian manusia dan terwujudnya kesehatan jiwa manusia. ${ }^{2}$

Dalam artikel ini, penulis akan memaparkan secara deskriptis-analitis psikologi dan kepribadian manusia menurut perspektif Al-Qur'an dan pendidikan Islam. Diharapkan gambaran tentang psikologi dan kepribadian manusia secara

${ }^{1}$ Muhammad Utsman Najati, Psikologi dalam Al-Qur'an: Terapi Qur'ani d lam Penyembuban Gangguan Kejiwaan, terj. M. Zaka al-Farisi (Bandung: Pustaka Setia, 2005), 11.

${ }^{2}$ Ibid., 19. 
komprehensif menurut perspektif Al-Qur'an dan pendidikan Islam akan menjadi bahan untuk merumuskan langkah edukatif lembaga pendidikan Islam dalam mendidik para siswanya sehingga menjadi manusia ideal dan manusia paripurna (insān kámil) sebagaimana dirumuskan Al-Qur'an.

\section{B. Pembahasan}

\section{Definisi Manusia}

Ketika berbicara tentang manusia, Al-Qur'an menggunakan tiga istilah pokok. Pertama, menggunakan kata yang terdiri atas huruf alif, nun, dan sin, seperti kata insan, ins, nās, dan uñas. Kedua, menggunakan kata basyar. Ketiga, menggunakan kata Bañi $\bar{A} d a m$ dan îrriyat $\bar{A}$ dam. ${ }^{3}$

Menurut M. Quraish Shihab, kata basyar terambil dari akar kata yang bermakna penampakan sesuatu dengan baik dan indah. Dari akar kata yang sama lahir kata basyarah yang berarti kulit. Al-Qur'an menggunakan kata basyar sebanyak 36 kali dalam bentuk tunggal dan sekali dalam bentuk musanna untuk menunjuk manusia dari sudut lahiriahnya serta persamaannya dengan manusia seluruhnya. ${ }^{4}$ Dengan demikian, kata basyar dalam Al-Qur'an menunjuk pada dimensi material manusia yang suka makan, minum, tidur, dan jalan-jalan. ${ }^{5}$ Dari makna ini lantas lahir makna-makna lain yang lebih memperkaya definisi manusia. Dari akar kata basyar lahir makna bahwa proses penciptaan manusia terjadi secara bertahap sehingga mencapai tahap kedewasaan. ${ }^{6}$ Allah swt. Berfirman dalam Q.S. ar-Rūm [30]: 20:

${ }^{3}$ M. Quraish Shihab, Wawasan Al-Qur'an: Tafsir Tematik atas Pelbagai Pers alan Umat (Bandung: Mizan, 2007), 367.

${ }^{4}$ Cek dalam Muhammad Fuad 'Abd al-Baqi, al-Mu'jam al-Mufahras li Alfăa. Al-Qur'an Al-Karim (Beirut: Dar al-Fikr, t.t.), 153-154.

${ }^{5}$ Aisyah Abdurrahman Bintusy Syathi', Manusia Sensitivitas Hermeneutika Al-Qur'an, terj. M. Adib al-Arief (Yogyakarta: LKPSM, 1997), 7.

${ }^{6}$ M. Quraish Shihab, Wawasan Al-Qur'an, 368. 
Dan, di antara tanda-tanda kekuasaan-Nya ialah dia menciptakan kamu dari tanah, kemudian tiba-tiba kamu (menjadi) manusia yang berkembang biak. (Q.S. ar-Rūm [30]: 20)

Selain itu, kata basyar juga dikaitkan dengan kedewasaan manusia yang menjadikannya mampu memikul tanggung jawab. Akibat kemampuan mengemban tanggung jawab inilah, maka pantas tugas kekhalifahan dibebankan kepada manusia. ${ }^{7} \mathrm{Hal}$ ini sebagaimana firman Allah berikut ini.

Dan (ingatlab), ketika Tubanmu berfirman kepada para malaikat, "Sesunggubnya Aku akan menciptakan seorang manusia dari tanah liat kering (yang berasal) dari lumpur hitam yang diberi bentuk. Maka, apabila Aku telah menyempurnakan kejadiannya, dan telah meniupkan ke dalamnya rub (ciptaan)-Ku, maka tunduklah kamu kepadanya dengan bersujud." (Q.S. al-Hijr [15]: 28-29)

Ingatlah ketika Tuhanmu berfirman kepada para malaikat, "Sesunggubnya Aku hendak menjadikan seorang khalifah di muka bumi." Mereka berkata, "Mengapa Engkau bendak menjadikan (khalifah) di bumi itu orang yang akan membuat kerusakan padanya dan menumpabkan darah, padahal kami senantiasa bertasbih dengan memuji Engkau dan mensucikan Engkau?" Tuban berfirman, "Sesunggubnya Aku mengetabui apa yang tidak. kamu ketahui." (Q.S. al-Baqarah [2]: 30)

Sementara itu, kata insän terambil dari kata ins yang berarti jinak, harmonis, dan tampak. ${ }^{8}$ Musa Asy'arie menambahkan bahwa kata insan berasal dari tiga kata: anasa yang berarti melihat, meminta izin, dan mengetahui; nasiya yang berarti lupa; dan aluns yang berarti jinak.' Menurut M. Quraish Shihab, makna jinak, harmonis, dan tampak lebih tepat daripada pendapat yang mengatakan bahwa kata insan terambil dari kata nasiya (lupa) dan

${ }^{7}$ Ibid., 368-369.

${ }^{8}$ M. Quraish Shihab, Wawasan Al-Qur'an, 369.

${ }^{9}$ Musa Asy'arie, Manusia Pembentuk Kebudayaan dalam Al-Qur'an (Yogy karta: LESFI, 1992), 19. 


\section{Aat Hidayat}

kata ñasa-yanūsu (berguncang). ${ }^{10}$ Dalam Al-Qur'an, kata insān disebut sebanyak 65 kali. ${ }^{11}$ Kata insän digunakan Al-Qur'an untuk menunjuk kepada manusia dengan seluruh totalitasnya, jiwa dan raga. ${ }^{12}$ Bahkan, lebih jauh Bintusy Syathi' menegaskan bahwa makna kata insān inilah yang membawa manusia sampai pada derajat yang membuatnya pantas menjadi khalifah di muka bumi, menerima beban takTif dan amanat kekuasaan. ${ }^{13}$

Dua kata ini, yakni basyar dan insān, sudah cukup menggambarkan hakikat manusia dalam Al-Qur'an. Dari dua kata ini, penulis menyimpulkan bahwa definisi manusia adalah makhluk Allah yang paling sempurna, yang diciptakan secara bertahap, yang terdiri atas dimensi jiwa dan raga, jasmani dan rohani, sehingga memungkinkannya untuk menjadi wakil Allah di muka bumi (khalifah Allah $\overline{f i}$ al-arḍ).

\section{Asal-Usul Penciptaan Manusia}

Al-Qur'an telah memberikan informasi kepada kita mengenai proses penciptaan manusia melalui beberapa fase: dari tanah menjadi lumpur, menjadi tanah liat yang dibentuk, menjadi tanah kering, kemudian Allah swt. meniupkan ruh kepadanya, lalu terciptalah Adam a.s. ${ }^{14} \mathrm{Hal}$ ini diisyaratkan Allah swt. dalam Q.S. Șàd [38]: 71-72.

Ingatlah ketika Tuhanmu berfirman kepada malaikat, "Sesunggubnya Aku akan menciptakan manusia dari tanah. Maka, apabila telah Kusempurnakan kejadiannya dan Kutiupkan kepadanya rub (ciptaan)Ku, maka hendaklah kamu menyungkur dengan bersujud kepadanya." (Q.S. Șàd [38]: 71-72)

\footnotetext{
${ }^{10}$ M. Quraish Shihab, Wawasan Al-Qur'an, 369.

${ }^{11}$ Muhammad Fuad 'Abd al-Baqi, al-Mu'jam al-Mufahras, 119-120.

${ }^{12}$ M. Quraish Shihab, Wawasan Al-Qur'an, 369.

${ }^{13}$ Aisyah Abdurrahman Bintusy Syathi', Manusia, 14.

${ }^{14}$ Ibid., 362.
} 
Perhatikan juga firman Allah swt. dalam Q.S. al-Hijr [15]: 28-29.

Dan (ingatlah), ketika Tubanmu berfirman kepada para malaikat, "Sesunggubnya Aku akan menciptakan seorang manusia dari tanah liat kering (yang berasal) dari lumpur bitam yang diberi bentuk. Maka, apabila Aku telah menyempurnakan kejadiannya, dan telab meniupkan ke dalamnya rub (ciptaan)-Ku, maka tunduklah kamu kepadanya dengan bersujud.” (Q.S. al-Hijr [15]: 28-29)

Dalam Al-Qur'an, kata ruh (ar-rūh) mempunyai beberapa arti. Pengertian ruh yang disebutkan dalam ayatayat yang menjelaskan penciptaan Adam a.s. adalah ruh dari Allah swt. yang menjadikan manusia memiliki kecenderungan pada sifat-sifat luhur dan mengikuti kebenaran. Hal ini yang kemudian menjadikan manusia lebih unggul dibanding seluruh makhluk yang lain. Karakteristik ruh yang berasal dari Allah ini menjadikan manusia cenderung untuk mengenal Allah swt. dan beribadah kepada-Nya, memperoleh ilmu pengetahuan dan menggunakannya untuk kemakmuran bumi, serta berpegang pada nilai-nilai luhur dalam perilakunya, baik secara individual maupun sosial, yang dapat mengangkat derajatnya ke taraf kesempurnaan insaniah yang tinggi. Oleh sebab itu, manusia layak menjadi khalifah Allah swt. ${ }^{15}$

Ruh dan materi yang terdapat pada manusia itu tercipta dalam satu kesatuan yang saling melengkapi dan harmonis. Dari perpaduan keduanya ini terbentuklah diri manusia dan kepribadiannya. Dengan memperhatikan esensi manusia dengan sempurna dari perpaduan dua unsur tersebut, ruh dan materi, kita akan dapat memahami kepribadian manusia secara akurat.

Kemudian, dalam ayat lain juga disebutkan mengenai permulaan penciptaan manusia yang berasal dari tanah.

Hai manusia, jika kamu dalam keraguan tentang kebangkitan (dari kubur), maka (ketahuilah) sesungguhnya kami

${ }^{15}$ Muhammad Utsman Najati, Psikologi dalam Al-Qur'an, 364. 
telah menjadikan kamu dari tanah, kemudian dari setetes mani, kemudian dari segumpal darah, kemudian dari segumpal daging yang sempurna kejadiannya dan yang tidak sempurna, agar kami jelaskan kepada kamu dan kami tetapkan dalam rahim, apa yang kami kehendaki sampai waktu yang sudah ditentukan, kemudian kami keluarkan kamu sebagai bayi, kemudian (dengan berangsurangsur) kamu sampailah kepada kedewasaan, dan di antara kamu ada yang diwafatkan dan (ada pula) di antara kamu yang dipanjangkan umurnya sampai pikun, supaya dia tidak mengetahui lagi sesuatu pun yang dahulunya telah diketahuinya. Dan, kamu lihat bumi ini kering, kemudian apabila telah kami turunkan air di atasnya, hiduplah bumi itu dan suburlah dan menumbuhkan berbagai macam tumbuh-tumbuhan yang indah. (Q.S. al-Hajj [22]: 5)

Kemudian kami jadikan saripati itu air mani (yang disimpan) dalam tempat yang kokoh (rabim). Kemudian air mani itu kami jadikan segumpal darah, lalu segumpal darah itu kami jadikan segumpal daging, dan segumpal daging itu kami jadikan tulang-belulang, lalu tulangbelulang itu kami bungkus dengan daging. Kemudian kami jadikan dia makbluk yang (berbentuk) lain. Maka, Mahasuci-lah Allah, Pencipta yang paling baik. (Q.S. al-Mu'minūn [23]: 13-14)

Itulah di antara sekian banyak ayat Al-Qur'an yang menjelaskan tentang asal-usul penciptaan manusia. Penciptaan manusia yang bermula dari tanah ini tidak berarti bahwa manusia dicetak dengan memakai bahan tanah seperti orang membuat patung dari tanah. Akan tetapi, penciptaan manusia dari tanah tersebut bermakna simbolik, yaitu saripati yang merupakan faktor utama dalam pembentukan jasad manusia. Penegasan AlQur'an yang menyatakan bahwa manusia diciptakan dari tanah ini merujuk pada pengertian jasadnya. Oleh karena itu, AlQur'an menyatakan bahwa kelak ketika ajal kematian manusia telah sampai, maka jasad itu akan kembali pula ke asalnya, yaitu tanah. ${ }^{16}$

${ }^{16}$ Musa Asy'arie, Manusia Pembentuk Kebudayaan, 63-65. 
Secara komprehensif, Umar Shihab memaparkan bahwa proses penciptaan manusia terbagi ke dalam beberapa fase kehidupan sebagai berikut. ${ }^{17}$ Pertama, fase awal kehidupan manusia yang berupa tanah. Manusia berasal dari tanah disebabkan oleh dua hal: (a) manusia adalah keturunan Nabi Adam a.s. yang diciptakan dari tanah; (b) sperma atau ovum yang menjadi cikal bakal manusia bersumber dari saripati makanan yang berasal dari tanah. Kedua, saripati makanan yang berasal dari tanah tersebut menjadi sperma atau ovum, yang disebut oleh Al-Qur'an dengan istilah nutfah. Ketiga, kemudian sperma dan ovum tersebut menyatu dan menetap di rahim sehingga berubah menjadi embrio ('alaqah). Keempat, proses selanjutnya, embrio tersebut berubah menjadi segumpal daging (mudgah). Kelima, proses ini merupakan kelanjutan dari mudgah. Dalam hal ini, bentuk embrio sudah mengeras dan menguat sampai berubah menjadi tulang belulang ('izăam). Keenam, proses penciptaan manusia selanjutnya adalah menjadi daging (laḥmah). Ketujuh, proses peniupan ruh. Pada fase ini, embrio sudah berubah menjadi bayi dan mulai bergerak. Kedelapan, setelah sempurna kejadiannya, akhirnya lahirlah bayi tersebut ke atas dunia.

Itulah beberapa deskripsi dan gambaran Al-Qur'an tentang proses penciptaan manusia. Secara garis besar, penggambaran tentang proses penciptaan manusia tersebut lebih bertumpu pada penciptaan manusia secara jasmani. Walaupun demikian, setelah proses penciptaan secara jasmani paripurna, akhhirnya Allah swt. meniupkan ruh kepada jasad manusia tersebut. Artinya, dalam proses penciptaan manusia, tetap tergabung proses secara jasmani dan secara rohani. Dan, proses inilah yang menjadikan manusia sebagai makhluk sempurna yang terdiri atas unsur jasmani dan unsur rohani.

${ }^{17}$ Penjelasan mengenai fase kehidupan manusia ini didasarkan pada Q.S. al-Mu'minūn [23]: 13-14. Lihat Umar Shihab, Kontekstualitas Al-Qur'an: Kajian Tematik atas Ayat-ayat Hukum dalam Al-Qur'an (Jakarta: Penamadani, 2005), 105106. 


\section{Kepribadian Manusia dalam Al-Qur'an}

Para psikolog memandang kepribadian sebagai struktur dan proses psikologis yang tetap, yang menyusun pengalamanpengalaman individu serta membentuk berbagai tindakan dan respons individu terhadap lingkungan tempat hidup. ${ }^{18}$ Dalam masa pertumbuhannya, kepribadian bersifat dinamis, berubahubah dikarenakan pengaruh lingkungan, pengalaman hidup, ataupun pendidikan. Kepribadian tidak terjadi secara serta merta, tetapi terbentuk melalui proses kehidupan yang panjang. Dengan demikian, apakah kepribadian seseorang itu baik atau buruk, kuat atau lemah, beradab atau biadab sepenuhnya ditentukan oleh faktor-faktor yang mempengaruhi dalam perjalanan kehidupan seseorang tersebut. ${ }^{19}$

\section{a. Pergulatan Psikologis}

Dalam kepribadian manusia terkandung sifat-sifat hewan dan sifat-sifat malaikat yang terkadang timbul pergulatan antara dua aspek kepribadian manusia tersebut. Adakalanya, manusia tertarik oleh kebutuhan dan syahwat tubuhnya, dan adakalanya ia tertarik oleh kebutuhan spiritualnya.

Al-Qur'an mengisyaratkan pergulatan psikologis yang dialami oleh manusia, yakni antara kecenderungan pada kesenangan-kesenangan jasmani dan kecenderungan pada godaan-godaan kehidupan duniawi. Jadi, sangat alamiah bahwa pembawaan manusia tersebut terkandung adanya pergulatan antara kebaikan dan keburukan, antara keutamaan dan kehinaan, dan lain sebagainya. Untuk mengatasi pergulatan antara aspek material dan aspek spiritual pada manusia tersebut dibutuhkan solusi yang baik, yakni dengan menciptakan keselarasan di antara keduanya.

\footnotetext{
${ }^{18}$ Muhammad Utsman Najati, Psikologi dalam Al-Qur'an, 359.

19 Zuhairini, dkk., Filsafat Pendidikan Islam (Jakarta: Bumi Aksara, 2004), 186.
} 
Di samping itu, Al-Qur'an juga mengisyaratkan bahwa manusia berpotensi positif dan negatif. Pada hakikatnya potensi positif manusia lebih kuat daripada potensi negatifnya. Hanya saja daya tarik keburukan lebih kuat dibanding daya tarik kebaikan. ${ }^{20}$

Potensi positif dan negatif manusia ini banyak diungkap oleh Al-Qur'an. Di antaranya ada dua ayat yang menyebutkan potensi positif manusia, yaitu Q.S. at-Tin [95]: 5 (manusia diciptakan dalam bentuk dan keadaan yang sebaik-baiknya) dan Q.S. al-Isrā' [7]: 70 (manusia dimuliakan oleh Allah dibandingkan dengan kebanyakan makhlik-makhluk yang lain). Di samping itu, banyak juga ayat Al-Qur'an yang mencela manusia dan memberikan cap negatif terhadap manusia. Di antaranya adalah manusia amat aniaya serta mengingkari nikmat (Q.S. Ibrahim [14]: 34), manusia sangat banyak membantah (Q.S. al-Kahfi [18]: 54), dan manusia bersifat keluh kesah lagi kikir (Q.S. al-Ma'arij [70]: 19). ${ }^{21}$

Sebenarnya, dua potensi manusia yang saling bertolak belakang ini diakibatkan oleh perseteruan di antara tiga macam nafsu, yaitu nafsu ammärah bi as-s̄', (jiwa yang selalu menyuruh kepada keburukan), lihat Q.S. Yusuf [12]: 53; nafsu lawwämah (jiwa yang amat mencela), lihat Q.S. al-Qiyāmah [75]: 1-2; dan nafsu mutma'innah (jiwa yang tenteram), lihat Q.S. al-Fajr [89]: 27-30. ${ }^{22}$ Konsepsi dari ketiga nafsu tersebut merupakan beberapa kondisi yang berbeda yang menjadi sifat suatu jiwa di tengah-tengah pergulatan psikologis antara aspek material dan aspek spiritual. ${ }^{23}$

\section{b. Pola-pola Kepribadian Menurut Al-Qur'an}

Kepribadian merupakan "keniscayaan", suatu bagian dalam (interior) dari diri kita yang masih perlu digali dan ditemukan agar sampai kepada keyakinan siapakah diri kita yang sesungguhnya. Dalam Al-Qur'an Allah telah menerangkan

\footnotetext{
20M. Quraish Shihab, Wawasan Al-Qur'an, 378.

${ }^{211}$ bid., 372 .

${ }^{22}$ Muhammad Utsman Najati, Psikologi dalam Al-Qur'an, 373-374.

${ }^{23}$ Ibid., 377.
} 
model kepribadian manusia yang memiliki keistimewaan dibanding model kepribadian lainnya. Di antaranya adalah Q.S. al-Baqarah [2]: 1-20. Rangkaian ayat ini menggambarkan tiga model kepribadian manusia, yakni kepribadian orang beriman, kepribadian orang kafir, dan kepribadian orang munafik. ${ }^{24}$

Berikut ini adalah sifat-sifat atau ciri-ciri dari masingmasing tipe kepribadian berdasarkan apa yang dijelaskan dalam rangkaian ayat tersebut.

\section{1) Kepribadian Orang Beriman (Mu'minūn)}

Dikatakan beriman bila ia percaya pada rukun iman yang terdiri atas iman kepada Allah swt., iman kepada para malaikatNya, iman kepada Kitab-kitab-Nya, iman kepada para rasulNya, percaya pada Hari Akhir, dan percaya pada ketentuan Allah (qadar/takdir). Rasa percaya yang kuat terhadap rukun iman tersebut akan membentuk nilai-nilai yang melandasi seluruh aktivitasnya. Dengan nilai-nilai itu, setiap individu seyogianya memiliki kepribadian yang lurus atau kepribadian yang sehat. Orang yang memiliki kepribadian lurus dan sehat ini memiliki ciri-ciri antara lain: (a) akan bersikap moderat dalam segala aspek kehidupan; (b) rendah hati di hadapan Allah dan juga terhadap sesama manusia; (c) senang menuntut ilmu; (d) sabar; (e) jujur, dan lain-lain. ${ }^{25}$

Gambaran manusia mukmin dengan segenap ciri yang terdapat dalam Al-Qur'an ini merupakan gambaran manusia paripurna (insān kamil) dalam kehidupan ini, dalam batas yang mungkin dicapai oleh manusia. Allah swt. menghendaki kita untuk dapat berusaha mewujudkannya dalam diri kita. Rasulullah saw. telah membina generasi pertama kaum mukminin atas dasar ciri-ciri tersebut. Beliau berhasil mengubah kepribadian mereka secara total serta membentuk mereka sebagai mukmin sejati yang mampu mengubah wajah sejarah dengan kekuatan pribadi

\footnotetext{
${ }^{24}$ Ibid., 381-382.

${ }^{25}$ Rani Anggraeni Dewi, “Kepribadian (Psikologi Al-Qur'an)”, www.p sakahati.com, diakses pada 28 Juni 2017.
} 
dan kemuliaan akhlak mereka. ${ }^{26}$ Singkatnya, kepribadian orang beriman dapat menjadi teladan bagi orang lain.

2) Kepribadian Orang Kafir (Käfirūn)

Sementara itu, ciri-ciri orang kafir yang diungkapkan dalam Al-Qur'an antara lain: (a) suka putus asa; (b) tidak menikmati kedamaian dan ketenteraman dalam kehidupannya; (c) tidak percaya pada rukun iman yang selama ini menjadi pedoman keyakinan umat Islam; (d) mereka tidak mau mendengar dan berpikir tentang kebenaran yang diyakini kaum Muslim; (e) mereka sering tidak setia pada janji, bersikap sombong, suka dengki, cenderung memusuhi orang-orang beriman; ( $f$ ) mereka suka kehidupan hedonis, kehidupan yang serba berlandaskan halhal yang bersifat material; tujuan hidup mereka hanya kesuksesan duniawi, sehingga sering kali berakibat ketidakseimbangan pada kepribadian; (g) mereka pun tertutup pada pengetahuan ketauhidan, dan lain-lain. ${ }^{27}$

Ciri-ciri orang kafir sebagaimana yang tergambar dalam AlQur'an tersebut menyebabkan mereka kehilangan keseimbangan kepribadian, yang akibatnya mereka mengalami penyimpangan ke arah pemuasan syahwat serta kesenangan lahiriah dan duniawi. Hal ini membuat mereka kehilangan satu tujuan tertentu dalam kehidupan, yaitu beribadah kepada Allah dan mengharap ridaNya untuk mengharap magfirah serta pahala-Nya di dunia dan akhirat. ${ }^{28}$

3) Kepribadian Orang Munafik (Munāfiqūn)

Munafik adalah segolongan orang yang berkepribadian sangat lemah dan bimbang. Adapun di antara sifat atau watak orang munafik yang tergambar dalam Al-Qur'an antara lain: (a) mereka "lupa" dan menuhankan sesuatu atau seseorang selain Allah swt.; (b) dalam berbicara mereka suka berdusta; (c)

${ }^{26}$ Muhammad Utsman Najati, Psikologi dalam Al-Qur'an, 384.

${ }^{27}$ Rani Anggraeni Dewi, “Kepribadian (Psikologi Al-Qur'an)”, www.p sakahati.com, diakses pada 28 Juni 2017.

${ }^{28}$ Muhammad Utsman Najati, Psikologi dalam Al-Qur'an, 387-389. 
mereka menutup pendengaran, penglihatan, dan perasaannya dari kebenaran; (d) orang-orang munafik ialah kelompok manusia dengan kepribadian yang lemah, peragu, dan tidak mempunyai sikap yang tegas dalam masalah keimanan; (e) mereka bersifat hipokrit, yakni sombong, angkuh, dan cepat berputus asa. ${ }^{29}$

Ciri kepribadian orang munafik yang paling mendasar adalah kebimbangannya antara keimanan dan kekafiran serta ketidakmampuannya membuat sikap yang tegas dan jelas berkaitan dengan keyakinan bertauhid. Dengan demikian, umat Islam sangat beruntung mendapatkan rujukan yang paling benar tentang kepribadian dibanding teori-teori lainnya, terutama diyakini rujukan tersebut adalah wahyu dari Allah swt. yang disampaikan kepada Nabi Muhammad saw., manusia teladan kekasih Allah. Oleh karena itu pula, Nabi Muhammad saw. diutus oleh Allah swt. ke muka bumi untuk memainkan peran sebagai model insān kamil bagi umat manusia. Kepribadian dalam kehidupan sehari-hari mengandung sifat-sifat manusiawi kita, alam pikiran, emosi, bagian interior kita yang berkembang melalui interaksi indra-indra fisik dengan lingkungan. Namun lebih dalam lagi, kepribadian sesungguhnya merupakan produk kondisi jiwa (nafs) kita yang saling berhubungan. Atau, dapat dikatakan pula bahwa kepribadian seseorang berbanding lurus dengan kondisi jiwanya (nafs). ${ }^{30}$

Berangkat dari teori kepribadian manusia sebagaimana dipaparkan di atas, maka kita dapat membagi kepribadian manusia menjadi dua macam, yaitu:

4) Kepribadian Kemanusiaan (Basyariyyah)

Kepribadian kemanusiaan di sini mencakup kepribadian individu dan kepribadian ummah. Kepribadian individu di antaranya melliputi ciri khas seseorang dalam bentuk sikap, tingkah laku, dan intelektual yang dimiliki masing-masing secara

\footnotetext{
${ }^{29}$ Rani Anggraeni Dewi, “Kepribadian (Psikologi Al-Qur'an)”, www.p sakahati.com, diakses pada 28 Juni 2017.

${ }^{30} \mathrm{Ibid}$.
} 
khas sehingga ia berbeda dengan orang lain. Dalam pandangan Islam, manusia memang mempunyai potensi yang berbeda (alfarq al-fardiyyah) yang meliputi aspek fisik dan psikis. Selanjutnya, kepribadian ummah meliputi ciri khas kepribadian muslim sebagai suatu ummah (bangsa/negara) muslim yang meliputi sikap dan tingkah laku ummah muslim yang berbeda dengan ummah lainnya, mempunyai ciri khas kelompok dan memiliki kemampuan untuk mempertahankan identitas tersebut dari pengaruh luar, baik ideologi maupun lainnya yang dapat memberikan dampak negatif. $^{31}$

5) Kepribadian Samawi (Kewahyuan)

Kepribadian samawi (kewahyuan) adalah corak kepribadian yang dibentuk melalui petunjuk wahyu dalam kitab suci Al-Qur'an, sebagaimana termaktub dalam firman Allah sebagai berikut.

Dan, bahwa (yang kami perintabkan ini) adalah jalan-Ku yang lurus, maka ikutilah Dia, dan janganlah kamu mengikuti jalan-jalan (yang lain), karena jalan-jalan itu mencerai-beraikan kamu dari jalannya. Yang demikian itu diperintabkean Allah agar kamu bertakwa. (Q.S. al-An'am [6]: 153)

\section{Kepribadian Manusia dalam Perspektif Pendidikan Islam}

Berbicara tentang kepribadian manusia dalam perspektif pendidikan Islam bisa dilihat dari dua aspek yang berkaitan dengan kepribadian manusia dalam Al-Qur'an sebagaimana telah dijelaskan di depan. Pembahasan terkait kepribadian manusia ini selanjutnya diarahkan pada peran dan fungsi pendidikan dalam membentuk kepribadian manusia sebagaimana diidealkan oleh Al-Qur'an.

Pertama, berkaitan dengan kepribadian dan aspek rohaniah manusia. Sebagaimana telah dipaparkan di depan, manusia dalam bahasa Arab berasal dari kata insan, yang berasal dari kata nasiya

${ }^{31}$ Ramayulis dan Samsul Nizar, Filsafat Pendidikan Islam: Telaah Sistem Pe didikan dan Pemikiran Para Tokohnya (Jakarta: Kalam Mulia, 2009), 263. 
yang berarti lupa dan al-uns atau anisa yang berarti jinak. Dari asal mula istilah manusia ini dapat disimpulkan bahwa manusia sebenarnya bersifat jinak, dalam arti dapat menyesuaikan diri dengan situasi atau kondisi lingkungan dan kehidupan yang dihadapinya. Manusia juga pandai beradaptasi dengan perubahan yang dijumpainya, baik berkaitan dengan perubahan alamiah maupun perubahan sosial. Dengan demikian, sejatinya manusia itu tidak liar, mampu menghargai tata aturan etika, sopan santun, serta aturan-aturan berbudaya. ${ }^{32}$ Untuk menjaga dan mewujudkan sifat manusia sebagaimana dijelaskan tadi, peran pendidikan Islam sangat urgen. Pendidikan Islam harus mampu menjaga kesejatian manusia sebagai makhluk berbudaya yang sarat dengan etika dan sopan santun. Hal ini dapat ditempuh melalui proses belajar. Sebab, dengan proses belajar inilah manusia dapat memahami sesuatu, baik secara potensial maupun aktual, sehingga manusia dapat merancang tindakan agar memberikan manfaat dan kemaslahatan bagi kehidupan dan sesamanya. ${ }^{33}$

Kedua, berkaitan dengan fisik serta aspek lahiriah dan jasmaniah manusia. Dalam wilayah ini bisa didefinisikan, manusia berasal dari bahasa Arab basyar yang berarti kulit manusia atau proses kematian. Artinya, dalam definisi ini, manusia adalah makhluk fisik yang akan berakhir dengan kematian. Dapat pula diartikan bahwa manusia adalah makhluk fisik yang dipengaruhi oleh dorongan kodrat alamiah seperti makan, minum, tidur, dan sebagainya. Melalui aspek fisik ini, gagasan, pemikiran, bahkan perasaan manusia dapat diwujudkan dalam bentuk hasil karya dan cipta manusia yang menempati ruang tertentu dan dapat diraba seperti lukisan, tarian, pahatan, dan sebagainya. ${ }^{34}$

Dari dua definisi tentang kepribadian manusia dalam perspektif pendidikan Islam tadi, dapat diberikan garis bawah

${ }^{32}$ Abuddin Nata, Filsafat Pendidikan Islam (Jakarta: Gaya Media Pratama, 2005), 80-82.

\footnotetext{
${ }^{33}$ Ibid., 86.

${ }^{34}$ Ibid., 86-87.
} 
bahwa manusia adalah makhluk yang memiliki kelengkapan aspek. Selain punya sisi jasmani, manusia juga memiliki aspek rohani. Pengertian tentang kepribadian manusia yang komprehensif dalam perspektif pendidikan Islam ini meniscayakan gerak dan wilayah pendidikan Islam harus menyentuh segala aspek manusia. Tidak hanya menyentuh aspek kognitif, tapi juga aspek afektif, dan aspek psikomotorik.

Tiga wilayah dan pekerjaan besar pendidikan Islam dalam membina kepribadian manusia ini selaras dengan definisi manusia sempurna (insān kamil) menurut Islam. Manusia sempurna, sebagaimana dijelaskan oleh Ahmad Tafsir, haruslah memiliki kelengkapan aspek yang mencakup: (a) jasmaninya sehat serta kuat; (b) akalnya cerdas serta pandai; (c) hatinya penuh keimanan kepada Allah. ${ }^{35}$ Dengan demikian, gerak dan langkah pendidikan Islam dalam membina kepribadian manusia harus selaras dengan tujuan pendidikan Islam yang bersifat komprehensif, yakni mencakup tujuan pada aspek jasmani, akal, dan hati.

\section{Simpulan}

Itulah beberapa gambaran mengenai psikologi dan kepribadian manusia dalam perspektif Al-Qur'an dan perspektif pendidikan Islam. Tentu gambaran di atas belum sepenuhnya berhasil meng-cover keseluruhan maksud Al-Qur'an dan perspektif pendidikan Islam mengenai manusia dengan segala kepribadiannya yang sangat kompleks. Sebab, begitu luasnya aspek kepribadian manusia sehingga usaha untuk mengungkap hakikat manusia merupakan pekerjaan yang sukar. Walaupun demikian, paling tidak penjelasan di atas dapat memberikan gambaran bahwa manusia memiliki dua potensi yang saling berlawanan, yaitu potensi baik dan potensi buruk. Dua potensi ini lantas memilah manusia ke dalam tiga kategori, yaitu mukmin, kafir, dan munafik.

${ }^{35}$ Ahmad Tafsir, Ilmu Pendidikan Islam (Bandung: Remaja Rosdakarya, 2013), 63. 
Pembinaan kepribadian manusia lewat pendidikan Islam yang baik akan menuntun manusia agar bisa memperkokoh potensi baiknya sehingga ia bisa memaksimalkan tugas utamanya untuk beribadah kepada Allah swt. ('abid) dan menjadi khalifah Allah swt. di muka bumi (khalifah fi al-ard). Sebaliknya, pembinaan kepribadian manusia yang kurang maksimal akan memerosokkan manusia ke dalam derajat yang sangat rendah, bahkan lebih rendah dari binatang ( $k a$ al-an'am bal bum adall). Oleh karena itu, menjadi tugas pendidikan Islam untuk menjaga dan membentuk kepribadian manusia, sehingga ia menjadi manusia paripurna (insän kamið) yang mampu memaksimalkan peran dan tugasnya sebagai hamba yang mengabdi kepada Allah swt. ("abid) dan menjadi khalifah Allah swt. di muka bumi (khaTifah fi al-ard). [] 


\section{DAFTAR PUSTAKA}

Asy'arie, Musa. Manusia Pembentuk Kebudayaan dalam Al-Qur'an. Yogyakarta: LESFI, 1992.

al-Baqi, Muhammad Fuad 'Abd. al-Mu'jam al-Mufahras li Alfăa. AlQur'an Al-Karim. Beirut: Dar al-Fikr, t.t.

Dewi, Rani Anggraeni. "Kepribadian (Psikologi Al-Qur'an)", www.pusakahati.com, diakses pada 28 Juni 2017.

Najati, Muhammad Utsman. Psikologi dalam Al-Qur'an: Terapi Qur'ani dalam Penyembuhan Gangguan Kejiwaan, terj. M. Zaka al-Farisi. Bandung: Pustaka Setia, 2005.

Nata, Abuddin. Filsafat Pendidikan Islam. Jakarta: Gaya Media Pratama, 2005.

Ramayulis dan Samsul Nizar. Filsafat Pendidikan Islam: Telaah Sistem Pendidikan dan Pemikiran Para Tokohnya. Jakarta: Kalam Mulia, 2009.

Shihab, M. Quraish. Wawasan Al-Qur'an: Tafsir Tematik atas Pelbagai Persoalan Umat. Bandung: Mizan, 2007.

Shihab, Umar. Kontekstualitas Al-Qur'an: Kajian Tematik atas Ayatayat Hukum dalam Al-Qur'an. Jakarta: Penamadani, 2005.

Syathi', Aisyah Abdurrahman Bintusy. Manusia Sensitivitas Hermeneutika Al-Qur'an, terj. M. Adib al-Arief. Yogyakarta: LKPSM, 1997.

Tafsir, Ahmad. Ilmu Pendidikan Islam. Bandung: Remaja Rosdakarya, 2013.

Zuhairini, dkk. Filsafat Pendidikan Islam. Jakarta: Bumi Aksara, 2004. 
Aat Hidayat

balaman ini bukan sengaja dikosongkan 